\title{
Design and evaluation of atorvastatin- loaded chitosan-hydroxyapatite composite bioscaffolds for wound-healing activity
}

\author{
T. Tejaswini ${ }^{1}$, M. Keerthana', M. Vidyavathi ${ }^{1 *}$ and R. V. Suresh Kumar $^{2}$
}

\begin{abstract}
Background: The study aimed at the formulation of atorvastatin-loaded chitosan-hydroxyapatite composite bioscaffolds and determination of its wound-healing activity on animals. Hydroxyapatite was prepared from the biowaste eggshell cross-linked with calcium chloride and loaded with atorvastatin. The prepared bioscaffold was characterized for physicomechanical properties, morphological studies, differential scanning calorimetry, and in vitro drug release study. In vitro antibacterial activity was determined using the agar diffusion method, and in vivo wound-healing activity was evaluated using the excision wound-healing model.

Results: Results exhibited that bioscaffold containing 1:1 ratio of chitosan to hydroxyapatite (Hac1) with calcium chloride of $1.5 \mathrm{~g}(\mathrm{Hbc3})$ and loaded with atorvastatin ( $\mathrm{Hcc} 3$ ) showed effective physicomechanical properties, i.e., thickness $(60 \mu \mathrm{m})$, swelling behavior (68\%), folding endurance (101), tensile strength (0.0283 Mpa), and burst time (1.9 s). Hcc3 scaffold was highly effective and exhibited the highest zone of inhibition against Bacillus subtilis (3.2 $\mathrm{cm})$, Staphylococcus aureus $(3.0 \mathrm{~cm})$, Escherichia coli $(3.5 \mathrm{~cm})$, and Pseudomonas aeruginosa $(2.7 \mathrm{~cm})$. The group treated with Hcc3 scaffold was significant in healing wounds by showing 100\% wound contraction.
\end{abstract}

Conclusion: It can be concluded from the study that atorvastatin-loaded chitosan-hydroxyapatite composite bioscaffolds may be a significantly more effective scaffold in healing excision wounds.

Keywords: Excision wound, Antibacterial, Hydroxyproline, Hexosamine, Tensile strength, Atorvastatin

\section{Background}

A wound can be defined as a disruption in the normal function and structure of the cell that occurs due to internal or external injury in the organs [1]. Acute wound is converted into chronic if not treated or failed to get the orderly reparative process for producing functional integrity within 3 months [2]. Chronic wounds are a socioeconomic problem around the globe characterized by infections through microbial attack, slow healing, and spreading of germs [3]. Non-healing chronic wounds cause substantial economic loss to the country and possess a healthcare burden. The conditions also reduce the

\footnotetext{
* Correspondence: vidyasur@rediffmail.com

'Institute of Pharmaceutical Technology, Sri Padmavati Mahila

Visvavidyalayam (Women's University), Tirupathi, Andhra Pradesh, India

Full list of author information is available at the end of the article
}

quality of life and increase diseases like diabetes and obesity [4]. Pathophysiologically, diabetes causes deterioration of wound healing by affecting the release of vascular endothelial growth factor (VEGF) that altered angiogenesis and delays the healing of wounds [5].

Skin-wound healing is a complex process that involves a series of events including hemostasis, inflammatory responses, proliferation, deposition of extracellular matrices, epithelialization, fibroplasia, contraction, and remodeling [6]. Topical delivery of drugs healing wounds has shown a magnificent role in clinical practice due to reduced systemic side effects and controlled drug delivery [7]. The topical use of cellular embryonic stem cell extracts in diabetic wounds is endowed with immunoregulatory and anti-inflammatory properties with improved wound healing in diabetic wounds [8]. However, the skin barrier is a 
major challenge for the bioactive compounds to cross the stratum corneum. Bioscaffolds are the novel delivery system that facilitates the regrowth of injured or wounded tissues by applying topically as a combination of bioactive compounds, biomaterials, and cells [9]. They create inductive microenvironments to improve cell infiltration and vascularization for fast chronic wound healing. As the healthcare system seeks precision medicine-based strategies, there is a need for the application of bioscaffolds as tunable treatment modalities for chronic wounds [10]. Natural biodegradable polymers have been gaining much attention for the fabrication of bioscaffolds because they provide a suitable environment for the growth of cells and tissues. Chitosan is a natural polymer derived from chitin that is widely used in the preparation of bioscaffolds due to its biological properties like biodegradability, biocompatibility, and bioactive nature [11]. Hydroxyapatite $\left[\mathrm{Ca}_{10}\left(\mathrm{PO}_{4}\right)_{6}(\mathrm{OH})_{2}\right]$ is a natural bioactive ceramic material obtained from a mineral source in the form of calcium phosphate that possesses agricultural and biological importance. Bioceramics are used in the preparation of bioscaffolds to restore defects or repair damaged tissues [12].

Several studies have been conducted earlier and screened lots of bioactive molecules using experimental and clinical models for the treatment of topical wounds. During this period, statins have emerged as a novel drug therapy for healing and repairing of wounds independent of their lipid-lowering property. It has reported that statins play a role in the regulation of angiogenesis by increasing the release of VEGF and thus ameliorating wound [13]. Atorvastatin is a prototype drug of statins that is employed for reducing low-density lipoprotein cholesterol levels [14]. Researchers found that atorvastatin accelerates tissue repair by modulating the expression of cytokines and proteins associated with cell-growth pathways [15]. Thus, based on the above literature, the present study was aimed at the preparation of atorvastatin-loaded chitosan-hydroxyapatite bioscaffold, characterization of its physicomechanical and morphological properties, and evaluation of its effect against wound.

\section{Methods}

\section{Drug, chemicals, and polymers}

Atorvastatin was obtained as a gift sample from Dr. Reddy's laboratories in Hyderabad, India. Chitosan was procured from Himedia Pvt. Ltd. Mumbai, India. Calcium chloride and other chemicals were purchased from Molychem Pvt. Ltd. Mumbai, India. Bacterial strains used in the study were Bacillus subtilis (ATCC 6633), Staphylococcus aureus (ATCC 6538), Escherichia coli (ATCC 25922), and Pseudomonas aeruginosa (ATCC 27853). All other chemicals and reagents were of analytical grade and used without further purification.
Preparation of hydroxyapatite from biowaste eggshell

The uncrushed eggshell wastes were collected from local areas of the city and washed with tap water to remove the cuticle layer and other impurities present in the shells. The shells were then crushed and boiled in water for half an hour in an oven with a heating rate of $5^{\circ} \mathrm{C} /$ min. The shells were dried at room temperature and powdered by using simple mill grinder (U-Tech, Semiautomatic, Ball Mill, India). The eggshell powder $(2 \mathrm{~g})$ was dissolved in $1 \mathrm{M}$ hydrochloric acid $(38 \mathrm{ml})$ with regular stirring at $40{ }^{\circ} \mathrm{C}$. The deionized water $(150 \mathrm{ml})$ was added to this solution after $1 \mathrm{~h}$ and stirred for further $15 \mathrm{~min}$ followed by centrifugation at $6000 \mathrm{rpm}$ for $90 \mathrm{~min}$. The $\mathrm{pH}$ of the resulting solution was adjusted to 9 with $\mathrm{NaOH}$ solution and then filtered to collect the precipitate (hydroxyapatite) and dried for $24 \mathrm{~h}$. FTIR analysis of the prepared product was performed for confirmation [16].

\section{Preparation of different composite bioscaffolds}

In situ co-precipitation and the solvent casting method were used for the preparation of different composite bioscaffolds. Table 1 shows the composition of different bioscaffolds.

\section{Chitosan-hydroxyapatite composite (Hac) bioscaffolds}

Hac bioscaffolds were prepared by dissolving chitosan aqueous solution (2\%) in distilled water containing acetic acid (1\%), and then it was added to the phosphoric acid solution (8.5\%). The ratio of chitosan to phosphoric acid was ranging from 20:80 to 80:20 for the final composition of chitosan/HAp composite. The solution of chitosan/phosphoric acid was added gradually to the HAp suspension and stirred thoroughly for $1 \mathrm{~h}$, and propylene glycol $(1 \mathrm{ml})$ was added as the plasticizer to the above mixture. The $\mathrm{pH}$ of the solution was adjusted to 9 by the addition of $\mathrm{NaOH}$. Five different compositions (Hac1 to Hac5) of chitosan/HAp composite bioscaffolds were prepared by taking 1 part of chitosan and different parts of HAp. The mixing was performed at room temperature, and dropping speed was controlled at 3.2 $\mathrm{ml} / \mathrm{min}$ using a tube pump. The resulting slurry was poured in Petri plates and kept in an oven at $60^{\circ} \mathrm{C}$. Then, the dried scaffolds were collected [17]. Table 1 shows the composition of different composite bioscaffolds.

\section{Cross-linked composite bioscaffolds}

The cross-linking agent was used in scaffolds to improve mechanical strength and degradation properties of biopolymers [18] needed to elicit better biological activity with ease of application on the living system. Hence, cross-linked composite bioscaffolds were prepared by adding calcium chloride to the Hac1, which 
Table 1 Composition of prepared different composite bioscaffolds

\begin{tabular}{|c|c|c|c|c|}
\hline \multirow[t]{2}{*}{ Formulations } & \multicolumn{2}{|c|}{ Ratios of chitosan to HAp } & \multirow{2}{*}{$\begin{array}{l}\text { Cross-linking agent } \\
\text { Calcium chloride (g) }\end{array}$} & \multirow[t]{2}{*}{ Atorvastatin $(\mathrm{mg}$} \\
\hline & Chitosan (2\%) & Hydroxyapatite & & \\
\hline \multicolumn{5}{|c|}{ Composite bioscaffolds } \\
\hline $\mathrm{Hacl}$ & 1 & 1 & - & - \\
\hline Hac2 & 1 & 2 & - & - \\
\hline Hac3 & 1 & 3 & - & - \\
\hline Hac4 & 1 & 4 & - & - \\
\hline Hac5 & 1 & 5 & - & - \\
\hline \multicolumn{5}{|c|}{ Cross-linked composite bioscaffolds } \\
\hline $\mathrm{Hbcl}$ & $1: 1$ & & 0.5 & - \\
\hline $\mathrm{Hbc2}$ & $1: 1$ & & 1 & - \\
\hline $\mathrm{Hbc3}$ & $1: 1$ & & 1.5 & - \\
\hline \multicolumn{5}{|c|}{ Atorvastatin-loaded composite bioscaffolds } \\
\hline $\mathrm{Hccl}$ & $1: 1$ & & 1.5 & 250 \\
\hline $\mathrm{Hcc} 2$ & $1: 1$ & & 1.5 & 500 \\
\hline $\mathrm{Hcc} 3$ & $1: 1$ & & 1.5 & 750 \\
\hline
\end{tabular}

was the best scaffold among blank composite bioscaffolds as it has the highest OD, i.e., 1 (Table 2). Calcium chloride was added in three different concentrations $(0.5 \mathrm{~g}, 1 \mathrm{~g}$, and $1.5 \mathrm{~g})$ as per the method described by Yamaguchi et al. [19]. A total of three cross-linked composite bioscaffolds were prepared, i.e., Hbc1 to Hbc3, by keeping a 1:1 ratio of chitosan and hydroxyapatite in Hac bioscaffolds.
Atorvastatin-loaded composite bioscaffolds

Atorvastatin-loaded composite bioscaffolds were prepared by solubilizing atorvastatin in methanol, and the solution was added to the cross-linked Hac bioscaffolds before the addition of plasticizer $(1 \mathrm{ml})$. A total of three atorvastatin-loaded composite bioscaffolds were prepared, i.e., Hcc1 to Hcc3, containing $1.5 \mathrm{~g}$ of calcium chloride with $250,500,750 \mathrm{mg}$ of atorvastatin,

Table 2 Physicomechanical properties of prepared composite bioscaffolds

\begin{tabular}{|c|c|c|c|c|c|c|c|c|c|}
\hline \multirow[t]{2}{*}{ Bioscaffold } & \multirow{2}{*}{$\begin{array}{l}\text { Thickness } \\
(\mu \mathrm{m})\end{array}$} & \multirow{2}{*}{$\begin{array}{l}\text { Folding } \\
\text { endurance }\end{array}$} & \multirow{2}{*}{$\begin{array}{l}\text { Swelling } \\
\text { behavior } \\
(\%)\end{array}$} & \multicolumn{3}{|c|}{ Tensile parameters } & \multicolumn{2}{|c|}{ Texture parameters } & \multirow{2}{*}{$\begin{array}{l}\text { OD } \\
\text { value }\end{array}$} \\
\hline & & & & $\begin{array}{l}\text { Max. force } \\
(N)\end{array}$ & $\begin{array}{l}\text { Max. elongation } \\
\text { (s) }\end{array}$ & $\begin{array}{l}\text { Tensile strength } \\
\text { (Mpa) }\end{array}$ & $\begin{array}{l}\text { Burst strength } \\
\text { (kg) }\end{array}$ & $\begin{array}{l}\text { Burst time } \\
(s)\end{array}$ & \\
\hline $\mathrm{Hacl}$ & $75 \pm 0.73$ & $300 \pm 1.15$ & $\begin{array}{l}212.8 \pm \\
1.2\end{array}$ & 0.0038 & 3.0 & 0.0037 & 0.0058 & 2.6 & 1 \\
\hline $\mathrm{Hac2}$ & $74 \pm 0.57$ & $300 \pm 1.15$ & $\begin{array}{l}188 \pm \\
0.57\end{array}$ & 0.0056 & 2.1 & 0.0054 & 0.0056 & 2.5 & 0.0410 \\
\hline Hac3 & $66 \pm 1.52$ & $280 \pm 1.23$ & $\begin{array}{l}170 \pm \\
0.58\end{array}$ & 0.0057 & 2.1 & 0.0055 & 0.0054 & 2.4 & 0.0021 \\
\hline $\mathrm{Hac} 4$ & $64 \pm 1.1$ & $231 \pm 2.30$ & $\begin{array}{l}113 \pm \\
1.52\end{array}$ & 0.0060 & 1.2 & 0.0058 & 0.0053 & 2.3 & 0 \\
\hline Hac5 & $60 \pm 2.64$ & $100 \pm 10$ & $94 \pm 2.08$ & 0.0203 & 1.2 & 0.0198 & 0.0053 & 2.3 & 0 \\
\hline \multicolumn{10}{|c|}{ Calcium chloride cross-linked bioscaffolds } \\
\hline $\mathrm{Hbcl}$ & $43 \pm 0.81$ & $241 \pm 0.76$ & $57 \pm 1.15$ & 0.0165 & 0.6 & 0.0161 & 0.0056 & 1.1 & 0 \\
\hline $\mathrm{Hbc2}$ & $52 \pm 1.15$ & $269 \pm 0.61$ & $43 \pm 0.57$ & 0.0301 & 0.2 & 0.0294 & 0.0058 & 0.8 & 0.0065 \\
\hline $\mathrm{Hbc3}$ & $54 \pm 1.06$ & $275 \pm 1.1$ & $60 \pm 2.08$ & 0.0764 & 1.1 & 0.0748 & 0.0062 & 0.95 & 1 \\
\hline \multicolumn{10}{|c|}{ Atorvastatin-loaded cross-linked bioscaffolds } \\
\hline $\mathrm{Hccl}$ & $51 \pm 0.57$ & $65 \pm 0.52$ & $66 \pm 1.0$ & 0.0177 & 0.4 & 0.0173 & 0.0056 & 1.8 & 0 \\
\hline $\mathrm{Hcc} 2$ & $56 \pm 0.6$ & $80 \pm 1.1$ & $63 \pm 1.52$ & 0.0228 & 0.5 & 0.0223 & 0.0057 & 1.8 & 0.21 \\
\hline $\mathrm{Hcc3}$ & $60 \pm 1.41$ & $101 \pm 1.41$ & $68 \pm 2.0$ & 0.0289 & 0.56 & 0.0283 & 0.0061 & 1.9 & 1 \\
\hline
\end{tabular}

Data are represented as mean \pm S.D. $(n=3)$ 
respectively, by keeping a 1:1 ratio of chitosan and hydroxyapatite in Hac bioscaffolds. Figure 1 shows the schematic representation of the preparation of atorvastatin-loaded composite bioscaffolds.

\section{Characterization of prepared bioscaffolds}

\section{Physicomechanical properties of prepared bioscaffolds}

The physicomechanical properties of prepared bioscaffolds were evaluated based on thickness, folding endurance, swelling behavior, tensile, and texture parameters. All parameters were evaluated in triplicate by a random selection of scaffold from three different sites of the prepared scaffolds. The thickness of the scaffolds was measured using a screw gauge in triplicate, and the average value was determined. Folding endurance was determined by repeatedly folding one scaffold at the same place until it breaks. The number of times the scaffolds could be folded at the same place without breaking gives the value of folding endurance. The tensile strength of the scaffolds was determined by using a texture analyzer (TA-XT PLUS stable system analyzer), and then maximum force $(\mathrm{N})$, maximum elongation at break (s), and tensile strength (Mpa) were calculated. The strength of a scaffold was quantified using a texture analyzer by a penetration test using a 5-mm cylinder probe, and the burst strength (rupture point) and burst time (time at which burst) were determined.

The swelling behavior of scaffolds was investigated at room temperature by exposing them to the PBS solution. A known weight of scaffold $\left(W_{\mathrm{d}}\right)$ material was placed in the PBS solution for $30 \mathrm{~min}$. The wet weight of the scaffold $(\mathrm{Ww})$ was determined after blotting the scaffold surface with filter paper, to remove excess PBS. The percentage of water absorption $\left(W_{\mathrm{SW}}\right)$ known as the degree of swelling of the scaffold was calculated from the below Eq. 1:

$$
W_{\mathrm{sw}}=\frac{W_{w}-W_{d}}{W_{d}} \times 100
$$

\section{Calculation of overall desirability factor}

Overall desirability factor was used for the selection of the best-desired bioscaffold combining all the responses to get the desired characteristics. The best scaffold should have a high thickness, swelling behavior, folding endurance, and tensile strength. The desirability functions of these responses were calculated using Eq. 2:

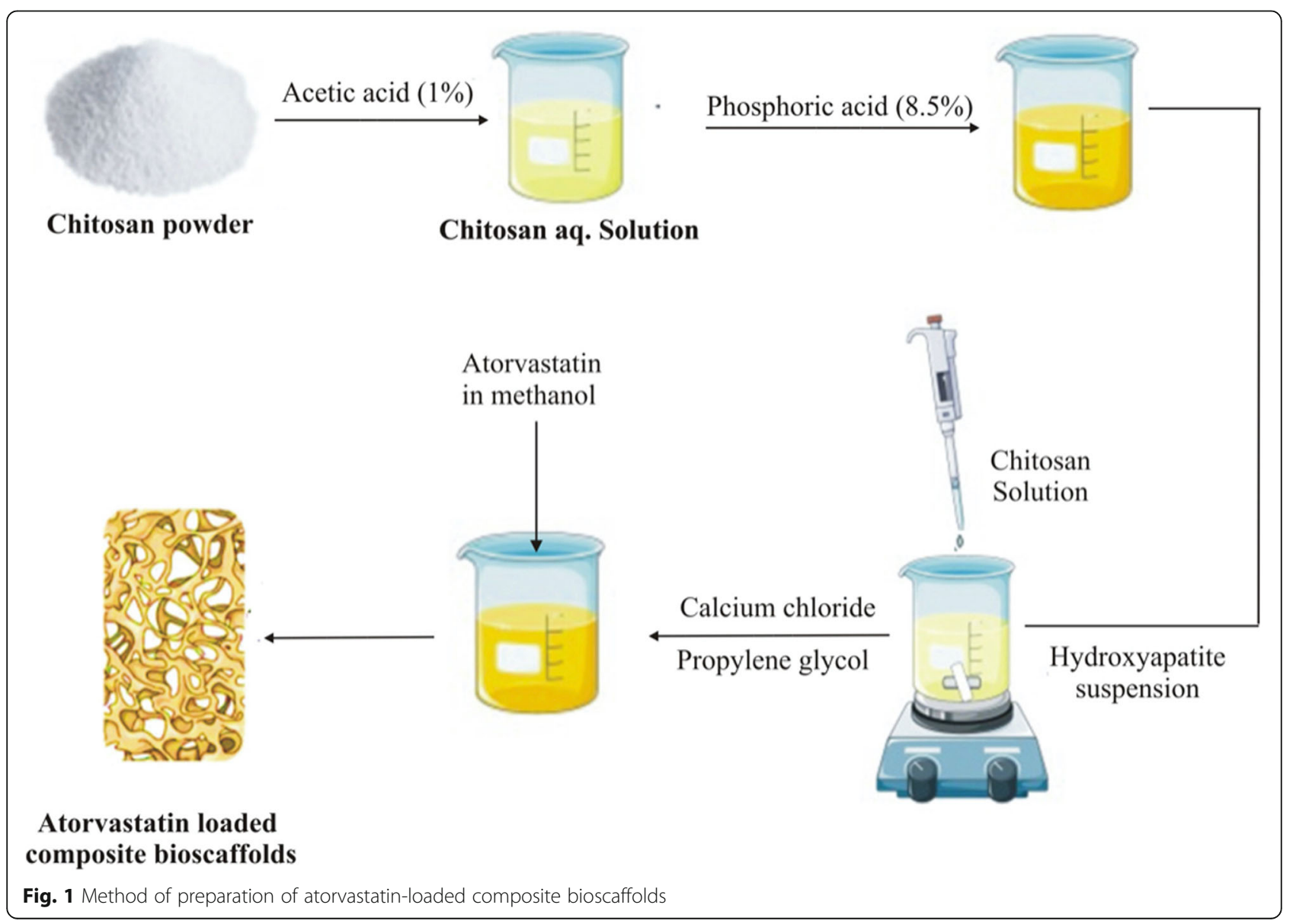




$$
\begin{aligned}
& \mathrm{ID}_{1}, \mathrm{ID}_{2}, \mathrm{ID}_{3} \& \mathrm{ID}_{4}=\mathrm{Y}_{\mathrm{i}}-\mathrm{Y}_{\mathrm{min}} / \mathrm{Y}_{\text {target }}-\mathrm{Y}_{\text {min }} \\
& \mathrm{ID}_{1}, \mathrm{ID}_{2}, \mathrm{ID}_{3} \& \mathrm{ID}_{4}=1 \text { for } \mathrm{Y}_{\mathrm{i}}>\mathrm{Y}_{\text {target }}
\end{aligned}
$$

where $\mathrm{ID}_{1}, \mathrm{ID}_{2}, \mathrm{ID}_{3}$, and $\mathrm{ID}_{4}$ are the individual desirability of thickness, swelling behavior, folding endurance, and tensile strength, respectively. The overall desirability values (OD) for each scaffold were calculated from the individual desirability values by using Eq. 3:

$$
\mathrm{OD}=\left(\begin{array}{llll}
\mathrm{ID}_{1} & \mathrm{ID}_{2} & \mathrm{ID}_{3} \ldots & \mathrm{ID}_{\mathrm{n}}
\end{array}\right)^{1 / \mathrm{n}}
$$

where $n$ is the number of desirable responses of the experiment.

The best bioscaffolds were selected by calculating OD from the results obtained from the physicomechanical parameters. The bioscaffold with the highest OD, i.e., 1 was selected as the best scaffold.

\section{Morphological studies of bioscaffolds}

The morphological characteristics of selected (Hac1 and $\mathrm{Hbc} 3$ ) bioscaffolds were determined by scanning electron microscope (SEM; Zeiss Ultra-60) to find the effect of cross-linking on morphology. Briefly, the scaffolds were taken and mounted directly on the SEM stub using a sticking tape. The samples were scanned in a highvacuum chamber with a focused electron beam, and SEM photomicrographs of the selected composite bioscaffolds were obtained.

\section{Differential scanning calorimetry}

Differential scanning calorimetry (DSC) thermograms of pure atorvastatin drug and atorvastatin-loaded composite bioscaffolds (Hcc3) was performed on a DSC-1 (Mettler Toledo, Switzerland) to find compatibility of atorvastatin with hydroxyapatite and chitosan on the application of thermal energy. Briefly, samples were placed in the aluminum pan of DSC and sealed hermetically. Scanning was performed with a rate of $10^{\circ} \mathrm{C} / \mathrm{min}$ under a temperature range of $40-240^{\circ} \mathrm{C}$ with a constant supply of nitrogen $(50 \mathrm{ml} / \mathrm{min})$ for the phase study of the test compound [20].

\section{In vitro release of atorvastatin from atorvastatin-loaded bioscaffolds}

In vitro, a drug diffusion study of atorvastatin-loaded composite bioscaffolds (Hcc3) was performed using the conventional dialysis sac method. The dialysis bag with a surface area of $16.68 \pm 1.34 \mathrm{~cm}^{2}$ containing a definite size of a scaffold consisting an equivalent to $750 \mathrm{mg}$ of the drug (Hcc3) was inserted in a beaker $(200 \mathrm{ml})$ containing phosphate buffer saline ( $\mathrm{pH} 7.4)$. The temperature of the assembly was maintained at $37^{\circ} \mathrm{C}$ with constant stirring until the completion of the experiment. The experiments were performed thrice. The external medium $(2 \mathrm{ml})$ was withdrawn from the beaker for analysis at a certain time interval (every $10 \mathrm{~min}$ ) and replaced with the fresh medium. The concentration of drugs in the samples was estimated using a UV/visible spectrophotometer at a wavelength of $246 \mathrm{~nm}$ which is the $\lambda \max$ of the drug.

\section{In vitro antibacterial activity of bioscaffolds by agar disc diffusion method}

In vitro antibacterial activity of the selected bioscaffolds was determined against four different bacterial strains (two gram-positive (Bacillus subtilis and Staphylococcus aureus) and two gram-negative (Escherichia coli and Pseudomonas aeruginosa) bacterial strains) with agar plate diffusion method by measuring the zone of growth inhibition of bacteria after incubation of $24 \mathrm{~h}$. It was done in triplicate with each bacteria, and the average diameter was noted.

\section{Inoculum preparation}

The selected bacteria were incubated overnight by plating on nutrient agar, and the bacterial colonies were emulsified in saline $(3 \mathrm{ml})$ to give the concentration of 3 $\times 10^{7} \mathrm{cfu} / \mathrm{ml}$ bacterial colonies. This suspension of bacterial colonies was employed in the agar disc diffusion method.

\section{Agar disc diffusion test}

The agar plates inoculated with respective cultures were maintained at a depth of approximately $5 \mathrm{~mm}$. One centimeter square size of selected scaffolds was placed on inoculated agar media and incubated at $37^{\circ} \mathrm{C}$. The zone of inhibition was calculated by measuring the diameter of inhibited growth after 24 and $48 \mathrm{~h}$ of incubation.

In vivo wound-healing activity of prepared bioscaffolds In vivo wound-healing activity was performed for the bioscaffolds that have shown a promising effect in vitro antibacterial test. The excision wound albino rat model was used to determine the efficacy of selected bioscaffolds.

\section{Experimental animals}

Pathogen-free adult female albino rats weighing 150$200 \mathrm{~g}$ were selected for the study. Animals were obtained from the central animal house of the institute. The study was approved by the Institutional Animal Ethical Committee (IAEC) with approval no. 1677/PO/Re/S/2012/ CPCSEA. The animals were housed in polypropylene cages under standard laboratory conditions of temperature $\left(25 \pm 2{ }^{\circ} \mathrm{C}\right)$ and relative humidity $(75-85 \%)$ with 12-h light and dark cycle. The rats were fed with 
standard laboratory chow (Hindustan Lever Limited, Mumbai) and water ad libitum.

\section{Experimental protocol}

The animals were divided into 3 groups each containing six animals. Group 1 was the control group untreated. Groups 2 and 3 were treated with $2 \mathrm{~cm}^{2}$ size of blank calcium chloride cross-linked scaffolds (Hbc3) and atorvastatin-loaded calcium chloride cross-linked scaffolds (Hcc3), respectively.

\section{Excision wound albino rat model}

The animals were anesthetized using ether and placed on the operation table in a normal position. The dorsal fur of the animals was shaved with an electric clipper, and the anticipated area $(2 \times 2 \mathrm{~cm})$ of the wound to be created was outlined on the back of the animals on the interscapular region ( $5 \mathrm{~mm}$ away from the ears). Fullthickness skin from the demarked area was excised to get a wound area of $2 \mathrm{~cm}^{2}$, and the wound was blotted with sterile gauze achieving homeostasis. The animals were treated for 28 days as mentioned in the experimental protocol. Wound contraction was measured every week as percent contraction after wound formation [21]. The specimen samples of healed wound tissues from each group were collected for histopathological analysis. The reduction in wound area was determined by the graphical method by counting several squares of retraced wound area on graph paper. The degree of wound healing was calculated as percent closure of the wound area from the original wound using the following Eq. 4:

$$
\text { Closure }(\%)=1-\frac{A_{d}}{A_{0}} \times 100
$$

where $A_{\mathrm{d}}$ is the wound area on corresponding days and $A_{0}$ is the wound area on day zero

\section{Biochemical estimation}

Granulation tissue was collected from all the animals on days 0 and 11. It was washed with cold saline $(\mathrm{NaCl}$, $0.9 \%)$ to remove blood clots and stored in normal saline solution at $-200^{\circ} \mathrm{C}$ for biochemical estimation.

\section{Determination of hydroxyproline}

Hydroxyproline content present in the collagen fibers of granulation tissue was determined in the connective tissue of the wound according to the method of Ponrasu et al. [21, 22]. Briefly, granulation tissues $(300 \mathrm{mg})$ were homogenized in $\mathrm{HCl}(6 \mathrm{~N}, 10 \mathrm{ml})$ and then transferred to the test tubes. The test tubes were then sealed and hydrolyzed by heating at $130{ }^{\circ} \mathrm{C}$ for $3 \mathrm{~h}$. The contents of the test tubes were collected in the graduated measuring cylinder followed by the addition of methyl red $(2 \mathrm{ml})$ and then shaken thoroughly. The solution was further shaken after the addition of $\mathrm{NaOH}(2.5 \mathrm{~N})$ until the pink color changes to yellow. The $\mathrm{pH}$ of the mixture was adjusted to $6-7$ by the addition of $\mathrm{HCl}(0.01 \mathrm{~N})$. The sample was diluted to $50 \mathrm{ml}$ with distilled water, and $2 \mathrm{ml}$ of the above sample was added with $1 \mathrm{ml}$ of chloramine- $\mathrm{T}$ solution. The contents were mixed and allowed to stand for $20 \mathrm{~min}$ at room temperature followed by the addition of $1 \mathrm{ml}$ per chloric acid then allowed to stand for $5 \mathrm{~min}$ at room temperature after gentle mixing. pDimethylaminobenzaldehyde (PDAB) in the volume of 1 $\mathrm{ml}$ was added to each test tube and shaken till no color was observed. All the tubes were heated in a hot water bath at $60^{\circ} \mathrm{C}$ for 20 min then cooled under running tap water. The absorbance of the purple-colored solution was measured at $557 \mathrm{~nm}$ by using a calorimeter. The standard curve was prepared, and the amount of hydroxyproline was expressed as $\mathrm{mg} / \mathrm{g}$ wt. of the tissue.

\section{Determination of hexosamine}

Hexosamine content in the body tissues was determined according to the method of Blix [23]. Briefly, granulation tissues $(300 \mathrm{mg})$ were homogenized in $\mathrm{HCl}(6 \mathrm{~N}, 10 \mathrm{ml})$ and then transferred to the test tubes. The test tubes were then sealed and hydrolyzed by heating at $98^{\circ} \mathrm{C}$ for $8 \mathrm{~h}$. The contents of the test tubes were collected in the graduated measuring cylinder, and the $\mathrm{pH}$ of the mixture was adjusted to 7 by the addition of $\mathrm{NaOH}(4 \mathrm{~N})$. The sample was diluted to $50 \mathrm{ml}$ with distilled water, and $2 \mathrm{ml}$ of the above sample was added with $1 \mathrm{ml}$ of $2 \%$ acetylacetone. The mixture was heated at $96^{\circ} \mathrm{C}$ for 40 min then cooled under running tap water, and $5 \mathrm{ml}$ of 96\% ethanol was added followed by the addition of $1 \mathrm{ml}$ of Ehrlich's reagent. The solution was thoroughly mixed and kept at room temperature for $1 \mathrm{~h}$. The absorbance of the pink color solution was measured at $530 \mathrm{~nm}$, and the amount of hexosamine was determined by comparing it with a standard curve. Hexosamine content was expressed as $\mathrm{mg} / \mathrm{g}$ wt. of the tissue.

\section{Histopathological analysis}

Histological tissues from wounded animals were collected on the zeroth and seventh day of treatment. It was fixed with $10 \%$ buffered formalin. They were processed by routine paraffin embedding technique, i.e., 5-6$\mu$-thick section were cut and stained with hematoxylin and eosin [24]. The slides were seen under a light microscope, and the effect of test drugs on wounded tissues was analyzed [25].

\section{Gross studies}

Gross study was performed by taking photographs of wounds from different groups for visual comparison. 


\section{Statistical analysis}

The results are expressed as mean \pm S.D. Statistical analysis was performed by two-way analysis of variance (ANOVA) using Bonferroni's multiple comparisons test. Statistical significance was set accordingly at $" p<0.05$, **" $p$ $<0.01$, and ${ }^{* * *} p<0.001$ in comparison to control group.

\section{Results}

\section{Physicomechanical properties of prepared bioscaffolds}

Table 2 shows the physicomechanical properties of calcium chloride and drug-loaded bioscaffolds. The ratio of chitosan and hydroxyapatite in Hac1 was 1:1 showing the highest thickness $(75 \mu \mathrm{m})$, folding endurance (300), and swelling behavior $(212.8 \%)$ among other ratios with hydroxyapatite. Therefore, this group was selected for cross-linking with calcium chloride. The cross-linked composite bioscaffold containing $1.5 \mathrm{~g}$ of calcium chloride (Hbc3) showed better physicomechanical properties as compared to the other two concentrations of calcium chloride. Hbc3 formulation was loaded with atorvastatin in three concentrations, i.e., $250 \mathrm{mg}, 500 \mathrm{mg}$, and 750 $\mathrm{mg}$, in which Hcc3 formulation containing $750 \mathrm{mg}$ of atorvastatin exhibited the best physicomechanical properties including thickness $(60 \mu \mathrm{m})$, folding endurance (101), swelling behavior (68\%), tensile strength $(0.0289$ $\mathrm{Mpa})$, burst strength $(0.0061 \mathrm{~kg})$, and burst time $(1.9 \mathrm{~s})$ with an overall desirability (O.D) value of 1 among other formulations.

\section{Morphological studies through scanning electronic microscopy (SEM)}

The morphological characteristics of bioscaffolds (Hac1 and Hbc3) by scanning electronic microscopic method are shown in Fig. 2a and b, respectively. SEM images revealed that the porosity of bioscaffold was decreased due to cross-linking with calcium chloride. The chitosan-hydroxyapatite bioscaffolds synthesized using $2 \%$ of chitosan was found to be highly porous with various irregular segregated structures as shown in Fig. 2a. Cross-linking with calcium chloride limited the porosity and showed irregular structures along with broken surfaces as shown in Fig. 2b. Thus, cross-linked bioscaffold (Hbc3) with $2 \%$ chitosan was selected for further studies.

\section{DSC thermograms}

DSC thermograms of pure drug and atorvastatin-loaded chitosan-hydroxyapatite composite bioscaffolds are shown in Fig. 3a and b, respectively. A sharp exotherm peak at $156^{\circ} \mathrm{C}$ was observed in the thermogram of pure atorvastatin, which indicates the melting point of the atorvastatin. The broad peak for the formulation Hcc3 was observed at $123^{\circ} \mathrm{C}$.

\section{In vitro drug release studies of prepared bioscaffolds}

Diffusion studies were conducted for atorvastatin-loaded chitosan-hydroxyapatite composite bioscaffolds to find the time taken to release the total drug. Results exhibited that half of the drug released up to $50 \mathrm{~min}$ in which 95\% of drug released up to $90 \mathrm{~min}$ (Fig. 4).

\section{In vitro antibacterial activity of prepared bioscaffolds}

Figure 5 shows the in vitro antibacterial activity of the selected bioscaffolds. Results showed that atorvastatinloaded bioscaffolds were effective in preventing the growth of microorganisms in a dose-dependent manner.

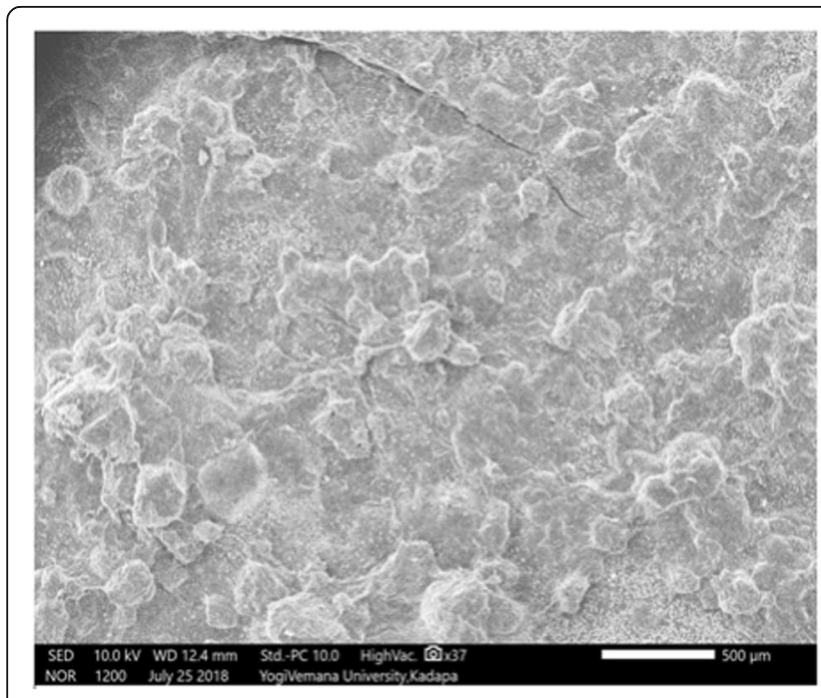

A

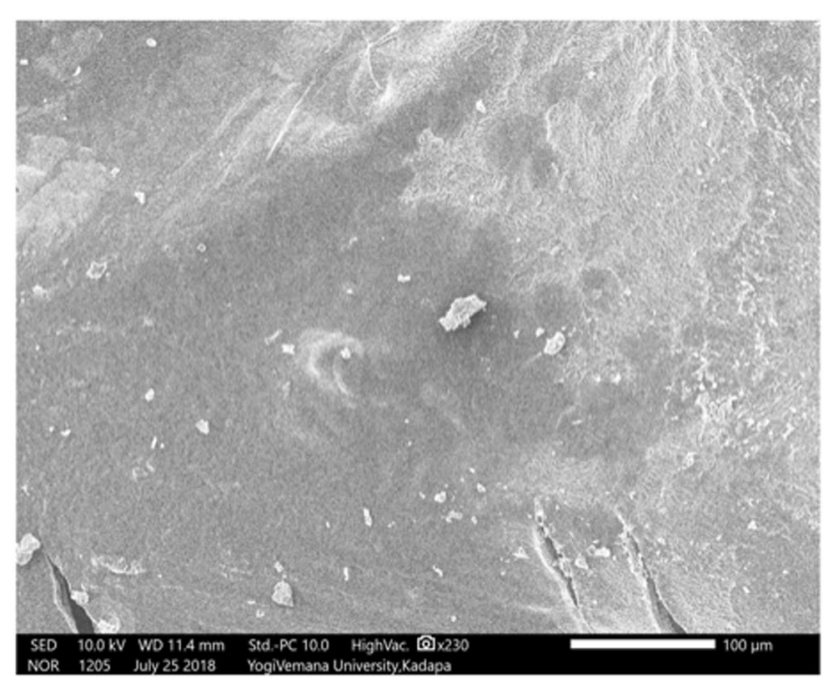

B

Fig. 2 SEM images of prepared bioscaffold. a Chitosan-hydroxyapatite bioscaffold. b Chitosan-hydroxyapatite calcium chloride cross-linked bioscaffold 


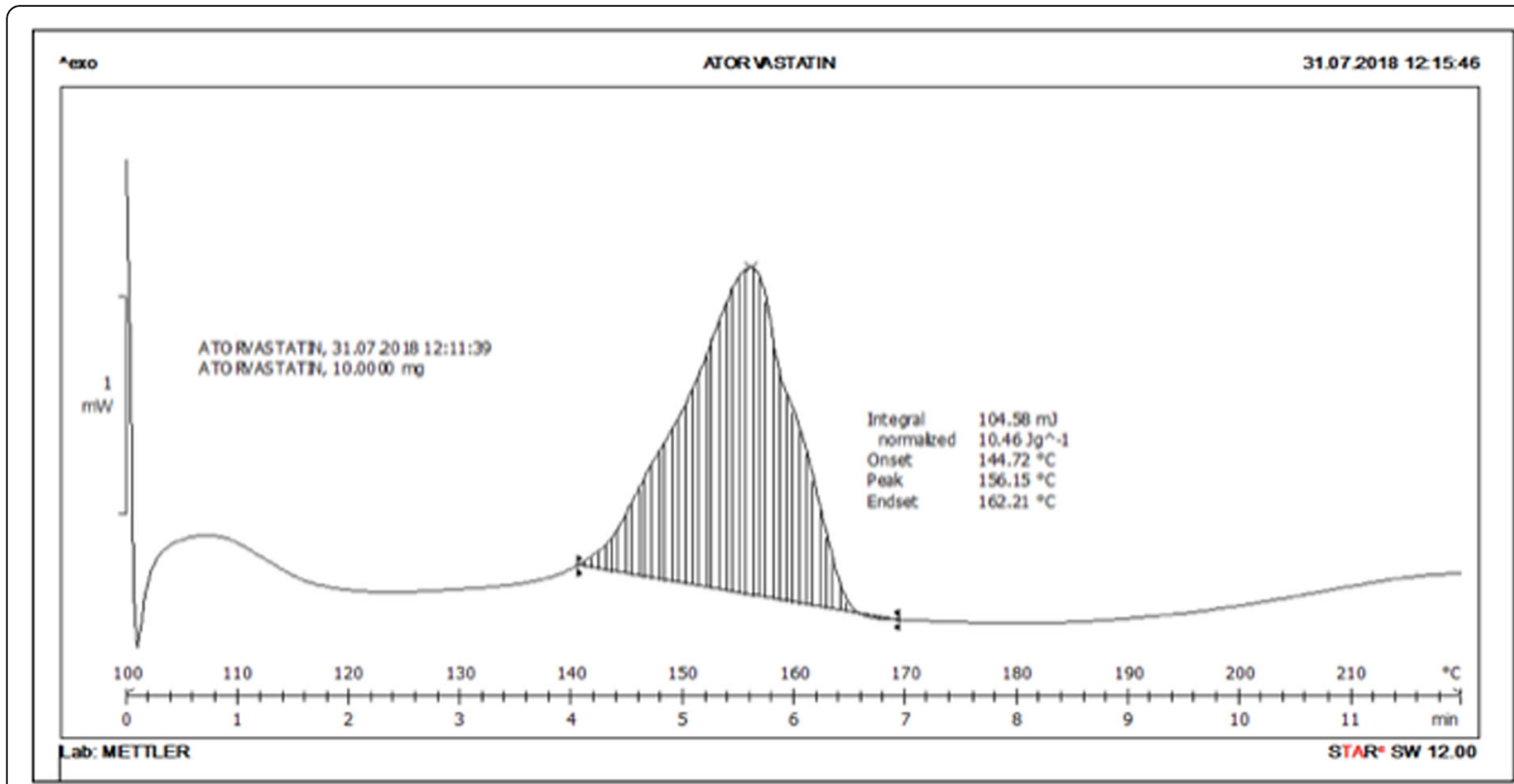

A

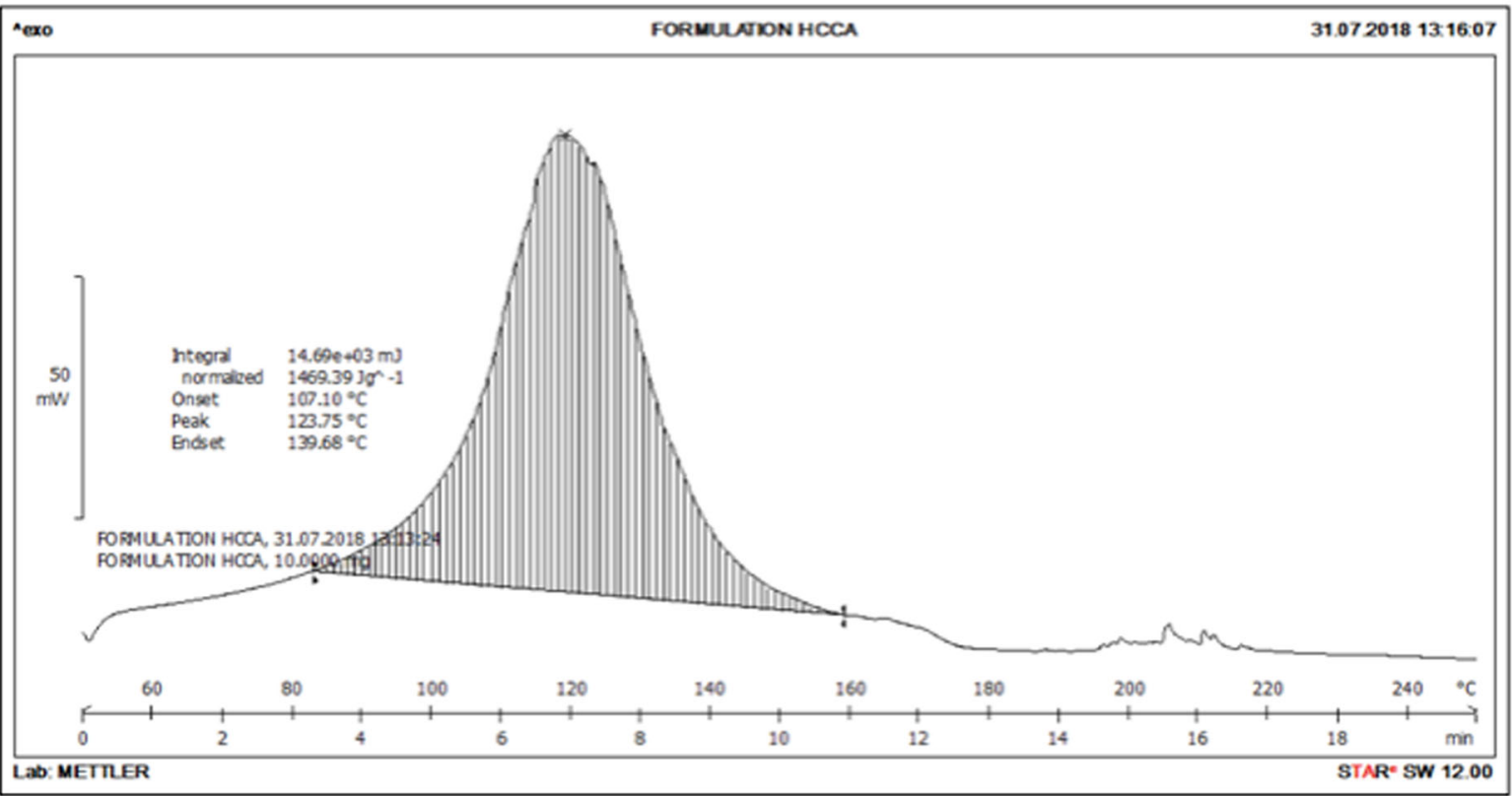

Fig. 3 DSC thermogram of prepared bioscaffold. a Pure drug atorvastatin. b Atorvastatin-loaded chitosan-hydroxyapatite bioscaffold

Hcc3 (750 mg of drug) showed the highest zone of inhibition against Bacillus subtilis $(3.2 \mathrm{~cm})$, Staphylococcus aureus $(3 \mathrm{~cm})$, Escherichia coli $(3.5 \mathrm{~cm})$, and Pseudomonas aeruginosa $(2.7 \mathrm{~cm})$ among all other groups. However, lower dose groups (Hcc1 and Hcc2) also showed antibacterial activity against all microorganisms.

\section{In vivo wound-healing activity of prepared bioscaffolds}

Table 3 shows the efficacy of prepared bioscaffolds on the excision wound-healing model. Wound contraction was observed on the 7th, 14th, 21st, and 28th post wounding day. Results exhibited that atorvastatin-loaded bioscaffolds ( $\mathrm{Hcc} 3)$ were effective in healing wounds on the 14th day onwards. Hcc3 group showed significant wound-healing activity in comparison to the control group. However, complete healing in $\mathrm{Hbc} 3$ group was seen on day 28. Photographs of wounds of all the groups are shown in Fig. 6.

\section{Biochemical Estimations}

Granulation tissue was collected from the treated groups of animals on the 0th and 11th to determine 


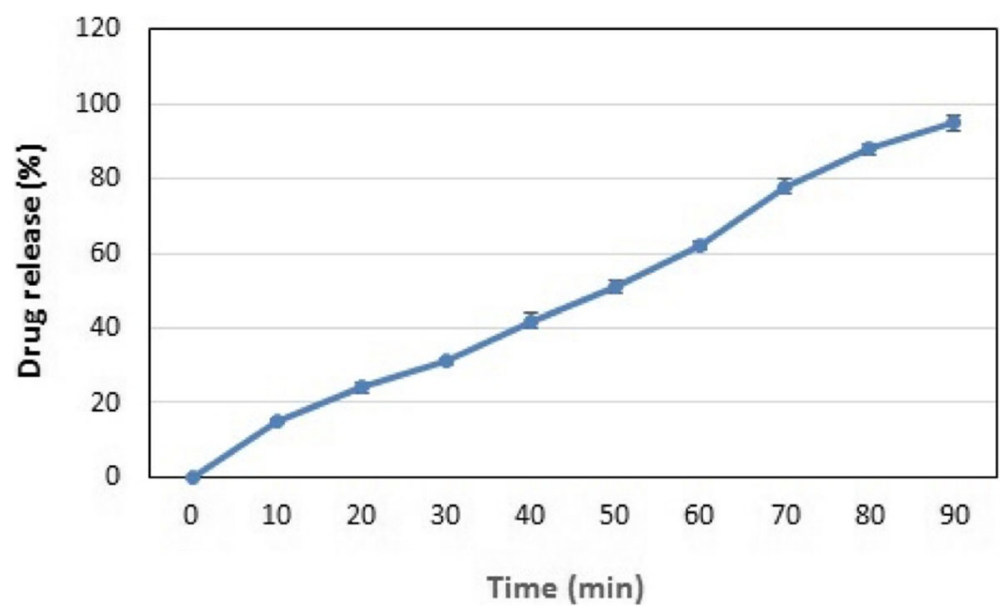

Fig. 4 In vitro drug release profile of prepared atorvastatin-loaded chitosan-hydroxyapatite composite bioscaffolds (Hcc3). Data are represented as mean \pm S.D. $(n=3)$

hydroxyproline and hexosamine contents. Table 4 shows the efficacy by bioscaffolds on hydroxyproline and hexosamine contents. Results exhibited that Hcc3 group significantly raised hydroxyproline $(11.257 \mathrm{mg} /$ $\mathrm{gm})$ and hexosamine $(10.524 \mathrm{mg} / \mathrm{gm})$ levels in animals on day 11 in comparison to the control group. Hbc was less effective in restoring hydroxyproline (4.581 $\mathrm{mg} / \mathrm{gm})$ and hexosamine $(3.664 \mathrm{mg} / \mathrm{gm})$ levels in animals on day 11.

\section{Histopathological studies}

Biopsy specimens for histopathological examination were collected on the 7th and14th day of treatment from

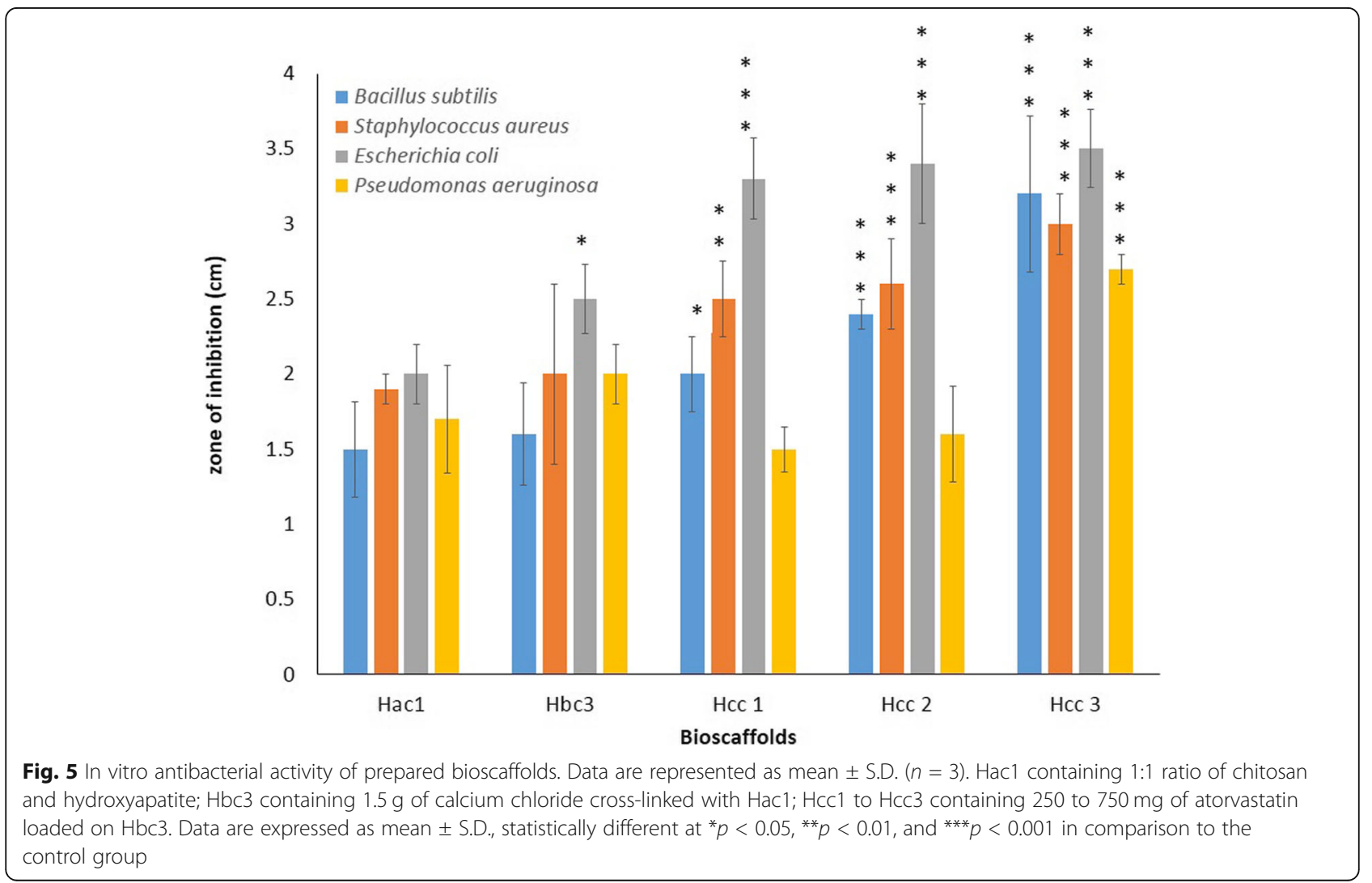


Table 3 Percentage of wound contraction at different time intervals in different groups

\begin{tabular}{|c|c|c|c|c|}
\hline \multirow[t]{2}{*}{ Groups } & \multicolumn{4}{|c|}{ Wound contraction (\%) } \\
\hline & 7th day & 14th day & 21st day & 28th day \\
\hline Control & $18 \pm 2.64$ & $45 \pm 1.41$ & $70 \pm 0.57$ & $91 \pm 2.16$ \\
\hline $\mathrm{Hbc3}$ & $52 \pm 1.25 * *$ & $64 \pm 1.15 *$ & $85 \pm 0.95 * *$ & Completely healed \\
\hline $\mathrm{Hcc3}$ & $70 \pm 0.95$ *** & Completely healed & Completely healed & Completely healed \\
\hline
\end{tabular}

Data are represented as mean \pm S.D. $(n=6)$. Significantly different at ${ }^{*} p<0.05,{ }^{* *} p<0.01$, and ${ }^{* * *} p<0.001$ in comparison to control group. Hbc3 containing 1.5 $\mathrm{g}$ of calcium chloride cross-linked with Hac1; Hcc3 containing $750 \mathrm{mg}$ of atorvastatin loaded on $\mathrm{Hbc3}$

all the groups, and photomicrographs are shown in Fig. 7. Hbc3 group showed complete healing on day 14th.

\section{Discussion}

Skin-wound healing is an important process that comprised of several events including the collaboration of cells and their products [26]. It is a complex process that is critical to maintaining the barrier function of the skin [27]. The prime preventable challenge for healing wounds is a topical infection by microbes. In the present study, atorvastatin-loaded bioscaffolds cross-linked with calcium chloride were prepared and evaluated for antimicrobial and woundhealing activities. Initially, five scaffolds (Hac1-Hac5) were prepared with five different concentrations of Hydroxyapatite $(0.5-2.5 \mathrm{~g})$ to determine in vitro physicomechanical parameters like thickness, folding endurance, swelling behavior, tensile, and texture parameters. Hydroxyapatite gives denser structure with lower porosity when observed microscopically as supported by Kong et al. and Escobar-Sierra et al. $[28,29]$. So, decreased porosity and dense inorganic

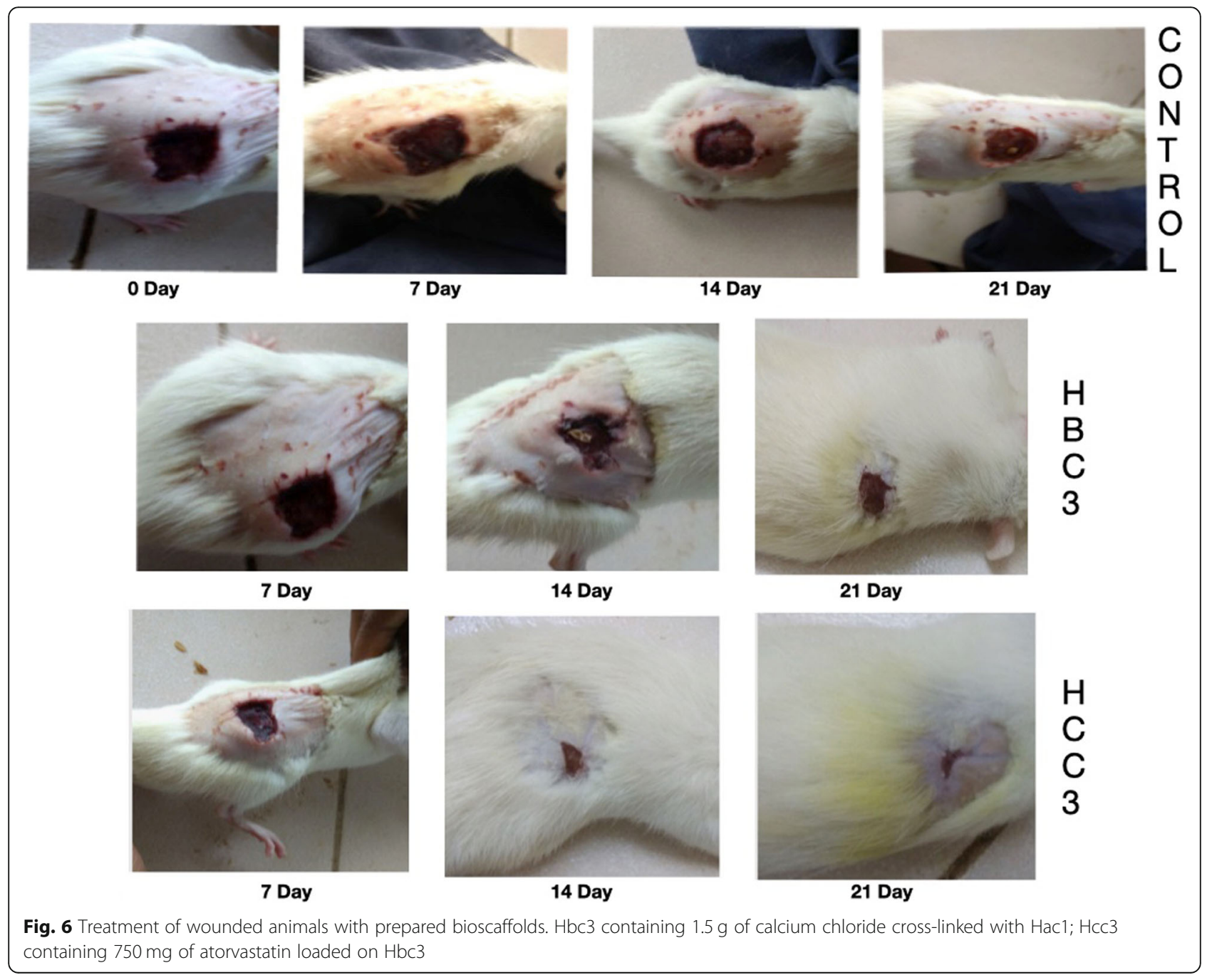


Table 4 Effect of bioscaffolds on hydroxyproline and hexosamine contents in animals

\begin{tabular}{|c|c|c|c|c|}
\hline \multirow[t]{2}{*}{ Groups } & \multicolumn{2}{|c|}{ Hydroxyproline content (mg/gm) } & \multicolumn{2}{|c|}{ Hexosamine content (mg/gm) } \\
\hline & Day 0 & Day 11 & Day 0 & Day 11 \\
\hline Control & $1.312 \pm 0.035$ & $0.828 \pm 0.062$ & $0.584 \pm 0.050$ & $0.123 \pm 0.056$ \\
\hline $\mathrm{Hbc3}$ & $2.024 \pm 0.069$ & $4.581 \pm 0.23 *$ & $2.718 \pm 0.63$ & $3.664 \pm 0.27 *$ \\
\hline $\mathrm{Hcc3}$ & $3.381 \pm 0.151$ & $11.257 \pm 0.079 * * *$ & $0.767 \pm 0.32$ & $10.524 \pm 0.203 * * *$ \\
\hline
\end{tabular}

Data are represented as mean \pm S.D. $(n=6)$. Significantly different at ${ }^{*} p<0.05,{ }^{* *} p<0.01$, and ${ }^{* * *} p<0.001$ in comparison to control group. Hbc3 containing 1.5 $\mathrm{g}$ of calcium chloride cross-linked with $\mathrm{Hac} 1 ; \mathrm{Hcc} 3$ containing $750 \mathrm{mg}$ of atorvastatin loaded on $\mathrm{Hbc3}$

nature of hydroxyapatite made the scaffolds with decreased folding endurance and swelling behavior with a slight increase in tensile parameters. Results exhibited that in vitro parameters were decreasing with increase in the concentration of hydroxyapatite. It made scaffolds more brittle due to its ceramic and non-film forming nature [17]. Present results were in agreement with the studies of Chhabra et al. who reported that chitosan in $2 \%$ concentration showed an effective scaffold for tissue engineering with minimum porosity [30]. The minimum porosity proved the improved cell attachment, a higher degree of proliferation, and well-spread morphology during healing process [31]. Physicomechanical studies showed that the prepared bioscaffolds have appropriated tensile strength for fast wound healing through close adherence with the skin for a long time.
Overall desirability was calculated for all five scaffolds in which Hac1 had the highest OD value, i.e., 1. Thus, it was selected as the best scaffold for further study. Calcium chloride was added to Hac1 in three different concentrations, i.e., $0.5 \mathrm{~g}, 1 \mathrm{~g}$, and $1.5 \mathrm{~g}$, because cross-linking increases the molecular mass of a polymer and the stability of film and also influences the porosity of the film. It resulted into a significant rise in tensile strength and burst strength along with other parameters with an increase in the concentration of the cross-linking agent. $\mathrm{Hbc} 3$ was selected as it possessed the highest OD for loading atorvastatin with three different doses, $250 \mathrm{mg}$, $500 \mathrm{mg}$, and $750 \mathrm{mg}$, and evaluated for in vitro physicomechanical parameters. No significant changes were found in the results of all physicomechanical properties except folding endurance and tensile parameters with

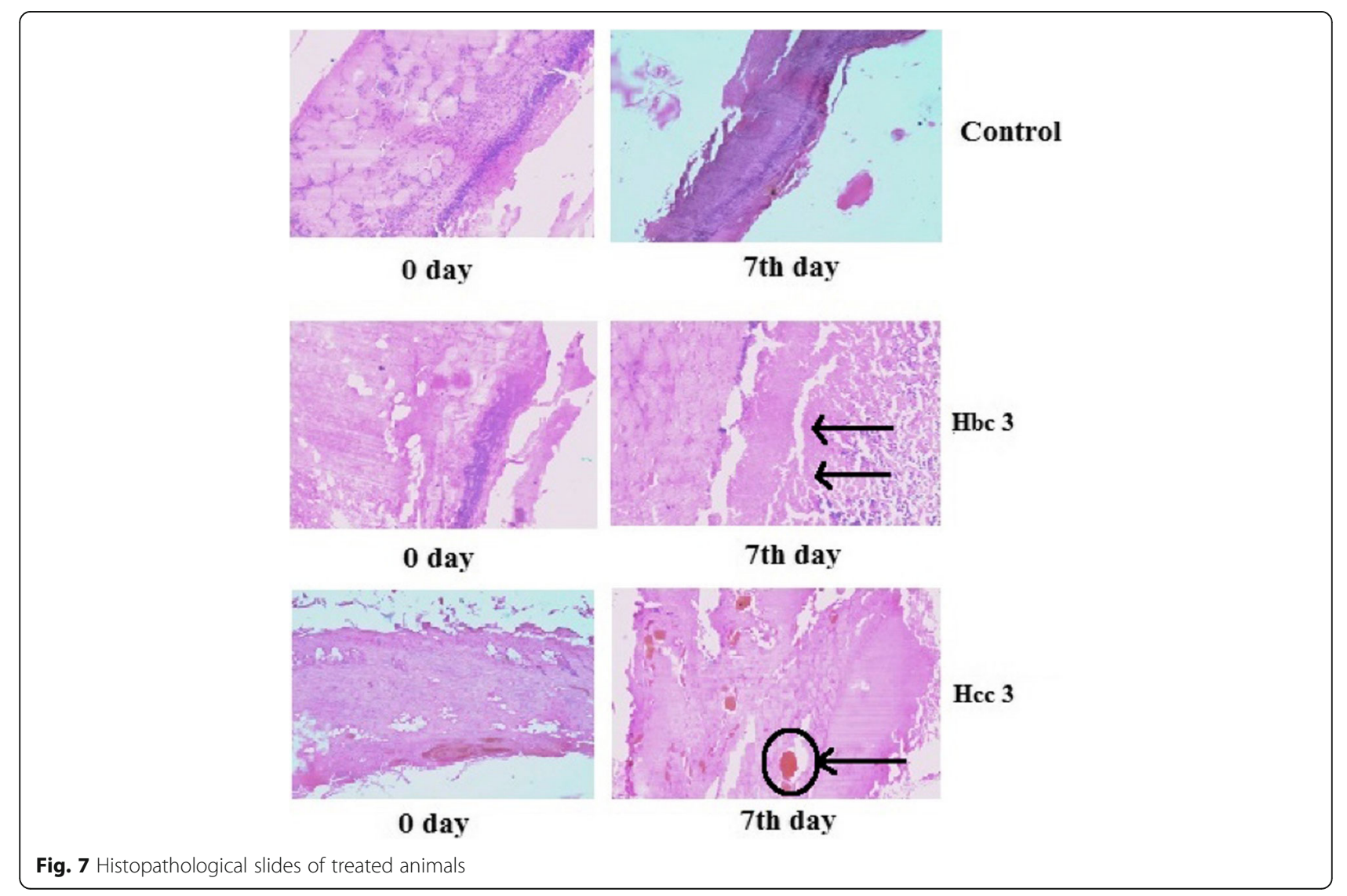


drug loading. The decrease in folding endurance, tensile, and texture parameters with an increase in drug loading (Table 2) may be due to the decreased effect of the crosslinking agent on polymers. The best drug-loaded crosslinked scaffold (Hcc3) has the highest OD value, i.e., 1.

SEM microphotographs of the chitosan-hydroxyapatite scaffold (Hac1) and cross-linked scaffold (Hbc3) are shown in Fig. 2a and b, respectively. The decreased porosity and reduced free space between molecules are visible in Hbc3 (Fig. 2b) and thus confirmed the crosslinking effect in Hbc3 [32] and the particles of hydroxyapatite embedded and dispersed along with chitosan [33]. The compatibility of atorvastatin with other excipients in the scaffold was evaluated by DSC analysis. DSC thermogram of pure atorvastatin depicted an exothermic peak at $156^{\circ} \mathrm{C}$; however, the $\mathrm{Hcc} 3$ has shown an exothermic peak at $123^{\circ} \mathrm{C}$, this shift might be due to decreased crystallinity of drug [34] and became amorphous led to uniform loading of the drug at the molecular level in the scaffold [35].

In vitro, drug release studies were conducted for the best drug-loaded bioscaffolds Hcc3 for 90 min that exhibited $95 \%$ of drug release within $90 \mathrm{~min}$. The $95 \%$ release of drug found might be due to the role of chitosan in bioadhesion and as a permeabilizer [36] or in absorption enhancement [37].

In vitro, antibacterial studies were carried out for the best-selected scaffolds (Hac1, Hbc3) and all drugloaded scaffolds by Agar disc diffusion technique using two gram-positive bacteria Bacillus subtilis and Staphylococcus aureus and two gram-negative bacteria E. Coli and Pseudomonas aeruginosa. Results exhibited that zone of inhibition for the best bioscaffolds was similar for all four organisms. It may be due to the same concentrations of hydroxyapatite in all selected formulations. Drug-loaded bioscaffolds have shown significantly increased zone of inhibition compared to blank scaffolds (Hac1 and Hbc3). Statins may inhibit biosynthesis pathway important for membrane stability as the statins have double effects to kill bacteria either by direct action or by decreasing the availability of host lipid for the growth of bacteria which is a new way to kill bacteria [38]. The significant antibacterial effect of statins against gramnegative bacteria was proved as the statins inhibit the enzyme HMG-CoA reductase, which plays an important role in the synthesis of isoprenes; additionally, it also hindered the production of cholesterol in bacteria $[38,39]$. Results also showed that gram-negative bacteria E. Coli and Pseudomonas aeruginosa were more susceptible to the drug-loaded bioscaffolds compared to gram-positive bacteria. It might be due to the thin wall of gram-negative bacteria than the gram-positive bacteria [40]. The permeability of $\mathrm{Ca}^{2+}$ ions of HAP is more in gram-negative bacteria due to thin cell walls. $\mathrm{Ca}^{2+}$ ions showed their effect on the oxygen consumed by the bacteria along with the production of free oxidative radicals that caused damage of cell membrane of the bacteria [41]. Among gram-negative bacteria, E. Coli has shown more susceptibility than $P$. aeruginosa (Fig. 5) due to synergistic effect of both drug and calcium on $E$. coli, whereas the effect of the drug on $P$. aeruginosa is less as suggested by earlier reports [38].

In vivo results exhibited that the prepared bioscaffolds were effective in healing excision wounds. Drugloaded bioscaffolds significantly contracted the wound size and bacterial zone of inhibition compared to blank scaffolds (without drug) (Table 3) [10]. Based on the results shown in Table 3 and Fig. 5, there is a direct relationship between wound contraction and the zone of inhibition against all bacteria. Other wound healing studies involved different atorvastatinloaded formulations and reported significant woundhealing activity in both animal and human models [42]. However, low solubility and bioavailability of atorvastatin may limit its maximal beneficial effect in wound healing [11]. Therefore, bioscaffold formulation enhanced the effectiveness of the drug and thus significantly healed the excision wound. The present study indicated that atorvastatin bioscaffolds significantly decreased wound area from day 8 onward which indicated early healing of wounds.

The response of skin in healing wounds is due to its interaction with several binding proteins [43]. During the repair process, the inflammatory cells help in the proliferation of endothelial cells that leads to neovascularization and synthesis of collagen; it resulted in reepithelialization of wounded tissue [44]. Hydroxyproline and hexosamine are matrix molecules that help in the synthesis of the new extracellular matrix. Earlier studies reported that an increased level of these molecules helps in wound healing of tissues [45]. Based on the histopathological photomicrographs, control wounds exhibited moderate inflammatory reaction and neovascularization on the seventh day whereas, Hbc3-treated wounds showed inflammatory reaction with fibrovascular proliferation on the seventh day and exhibited early epithelialization and fibroblastic proliferation on wound surface on the seventh day and slight appearance of normal skin at wound area. The early proliferation of fibroblasts was more evident in Hcc3 treated wounds suggesting accelerated wound healing (Fig. 7). Histopathological studies also revealed healing of wounds with normal epithelization, restoration of tissues, and fibrosis within the skin in Hcc3-treated animals. Similar results were reported by Murthy et al. in the excision wound-healing model [46]. 


\section{Conclusion}

The prepared formulation of atorvastatin-loaded chitosan-hydroxyapatite bioscaffolds promotes remarkable wound-healing activity. It exhibited significant wound-healing activity and may be suggested as an alternative drug therapy in treating the cutaneous wound. The present study may provide a novel approach for the efficient healing of wounds using atorvastatin bioscaffolds.

\section{Abbreviations \\ VEGF: Vascular endothelial growth factor; Hac: Chitosan-hydroxyapatite composite; DSC: Differential scanning calorimetry; IAEC: Institutional Animal Ethical Committee; PDAB: p-Dimethylaminobenzaldehyde; SEM: Scanning electronic microscopy}

\section{Acknowledgements}

The authors are thankful to the DST FIST and DST CURIE funded to institute for providing all facilities required during the experiment. We are also showing our gratitude towards ProbeCell: scientific writing services for proofreading and editing this article.

\section{Authors' contributions}

TL designed the work. MK have drafted the work or substantively revised it. MV contributed in the acquisition, analysis, and interpretation of the data. RVSK did the guidance and mentoring. The authors read and approved the manuscript.

\section{Funding}

No funding was received.

\section{Availability of data and materials}

All data and materials are available upon request.

\section{Ethics approval and consent to participate}

The animal study was approved by the Institutional Animal Ethical Committee (approval no. 1677/PO/Re/S/2012/CPCSEA).

\section{Consent for publication}

Not applicable.

\section{Competing interests}

The authors declare that they have competing interest.

\section{Author details}

${ }^{1}$ Institute of Pharmaceutical Technology, Sri Padmavati Mahila Visvavidyalayam (Women's University), Tirupathi, Andhra Pradesh, India. ${ }^{2}$ Department of Surgery and Radiology, S. V. Veterinary University, Tirupati, Andhra Pradesh, India.

\section{Received: 5 June 2020 Accepted: 4 October 2020}

Published online: 04 December 2020

\section{References}

1. Dernell WS (2006) Initial wound management. Vet Clin North Am Small Anim Pract 36(4):713-738

2. Järbrink K, Ni G, Sönnergren H (2016) Prevalence and incidence of chronic wounds and related complications: a protocol for a systematic review. Syst Rev 5(1):152

3. Singh P, Khosa RL, Srivastava S, Mishra G, Jha KK, Srivastava S (2014) Pharmacognostical study and establishment of quality parameters of aerial parts of Costusspeciosus-a well known tropical folklore medicine. Asian Pac J Trop Biomed 4(6):486-491

4. Järbrink K, Ni G, Sönnergren H (2017) The humanistic and economic burden of chronic wounds: a protocol for a systematic review. Syst Rev 6(1):1-7

5. Farsaei S, Khalili H, Farboud ES (2012) Potential role of statins on wound healing: review of the literature. Int Wound J 9(3):238-247

6. Robson MC, Steed DL, Franz MG (2001) Wound healing: biologic features and approaches to maximize healing trajectories. Curr Probl Surg 38(2):72-140
7. LuísMorais RA, Gravinez PA, Esselin de Sousa LM, Silva MP, Ribeiro PG (2016) Evaluation of skin absorption of drugs from topical and transdermal formulations. Braz J Pharm Sci 52(3):527-544

8. Loretelli C, Nasr MB, Giatsidis G, Bassi R, Lancerotto L, D'Addio F, Abdelsalam A (2020) Embryonic stem cell extracts improve wound healing in diabetic mice. Acta Diabetol:1-8

9. Garg T, Singh O, Arora S, Murthy R (2012) Scaffold: a novel carrier for cell and drug delivery. Crit Rev Ther Drug Carrier Syst 29(1):1-63

10. Dickinson LE, Gerecht S (2016) Engineered biopolymeric scaffolds for chronic wound healing. Front Physiol 7:1-12

11. Rodríguez-Vázquez M, Vega-Ruiz B, Ramos-Zúñiga R, Saldaña-Koppel DA, Quiñones-Olvera LF. (2015) Chitosan and its potential use as a scaffold for tissue engineering in regenerative medicine. Biomed Res Int. https://doi.org/ 10.1155/2015/821279.

12. Baino F, Novajra G, Vitale-Brovarone C (2015) Bioceramics and scaffolds: a winning combination for tissue engineering. Front Bioeng Biotechnol 3(202):1-17

13. Bitto A, Minutoli L, Altavilla D, Polito F, Fiumara T, Marini H, Galeano M, Calò M, Lo Cascio P, Bonaiuto M, Migliorato A, Caputi AP, Squadrito F (2008) Simvastatin enhances VEGF production andameliorates impaired wound healing in experimental diabetes. Pharmacol Res 57(2):159-169

14. Qiu S, Zhuo W, Sun C, Su Z, Yan A, Shen L (2017) Effects of atorvastatin on chronic subdural hematoma: a systematic review. Medicine (Baltimore) 96(29):e7616

15. Suzuki-Banhesse VF, Azevedo FF, Araujo EP (2015) Effect of atorvastatin on wound healing in rats. Biol Res Nurs 17(2):159-168

16. Maji K, Dasgupta S, Pramanik K, Bissoyi A (2016) Preparation and evaluation of gelatin-chitosan-nanobioglass 3D porous scaffold for bone tissue engineering. Int J Biomater:1-14

17. Yamaguchi I, Tokuchi K, Fukuzaki H, Koyama Y, Takakuda K, Momma H (2001) Preparation and mechanical properties of chitosan/hydroxyapatite nanocomposites. Key Eng Mater 192-195:673-676

18. Bi L, Cao Z, Hu Y, Song Y, Yu L, Yang B, Han Y (2011) Effects of different cross-linking conditions on the properties of genipin-cross-linked chitosan/ collagen scaffolds for cartilage tissue engineering. J Mater Sci Mater Med 22(1):51-62

19. Yamaguchi I, Tokuchi K, Fukuzaki H, Koyama Y, Takakuda K, Monma H, Tanaka J (2001) Preparation and microstructure analysis of chitosan/ hydroxyapatite nanocomposites. J Biomed Mater Res 55:20-27

20. León-Mancilla BH, Araiza-Téllez MA, Flores-Flores JO, Piña-Barba MC (2016) Physico-chemical characterization of collagen scaffolds for tissue engineering. J Appl Res Technol 14(1):77-85

21. Pawar RS, Chaurasiya PK, Rajak H, Singour PK, Toppo FA, Jain A (2013) Wound healing activity of Sida cordifolia Linn. in rats. Ind J Pharmacol 45: 474-478

22. Ponrasu T, Jamuna S, Mathew A (2013) Efficacy of I-proline administration on the early responses during cutaneous wound healing in rats. Amino Acids 45:179-189

23. Blix G (1948) The determination of hexosamines according to Elson and Morgan. Acta ChemScand 2:467-473

24. Taqi SA, Sami SA, Sami LB, Zaki SA (2018) A review of artifacts in histopathology. J Oral Maxillofac Pathol 22(2):279

25. Drury RA, Wallington EA (1980) Carleton's histological techniques, 5th edn. Oxford University Press, New York

26. Gonzalez AC, Costa TF, Andrade ZA, Medrado AR (2016) Wound healing - a literature review. An Bras Dermatol 91(5):614-620

27. Han G, Ceilley R (2017) Chronic wound healing: a review of current management and treatments. Adv Ther 34(3):599-610

28. Kong L, Gao Y, Lu G, Gong Y, Zhao N, Zhang X (2006) A study on the bioactivity of chitosan/nano-hydroxyapatite composite scaffolds for bone tissue engineering. Eur Polym J 42(12):3171-3179

29. Escobar-Sierra DM, Martins-Martins J, Ossa-Orozco CP (2015) Chitosan/ hydroxyapatite scaffolds for tissue engineering manufacturing method effect comparison. Rev Facult Ing Univ de Anti (75):24-35

30. Chhabra P, Tyagi P, Bhatnagar A, Mittal G, Kumar A (2016) Optimization, characterization, and efficacy evaluation of $2 \%$ chitosan scaffold for tissue engineering and wound healing. J Pharm Bioallied Sci 8(4):300-308

31. Venkatesan J, Kim SK, Wong TW (2015) Chitosan and its application as tissue engineering scaffolds. In: Nanotechnology applications for tissue engineering. William Andrew Publishing, pp 133-147

32. Koivurinta J, Hämäläinen ER, Kellomäki M (2008) The effect of cross-linking time on a porous freeze-dried collagen scaffold using 1-ethyl-3-(3- 
dimethylaminopropyl) carbodiimide as a cross-linker. J Appl Biomat Biomech 6(2):89-94

33. Pistone A, Celesti C, Piperopoulos E, Ashok D, Cembran A, Tricoli A (2019) Engineering of chitosan-hydroxyapatite-magnetite hierarchical scaffolds for guided bone growth. Mater. 12(14):2321

34. Lavanya V, Rajeswari P, Vidyavathi M, Sureshkumar RV (2020) Preparation of atorvastatin loaded chitosan nanoparticles: in vitro and in vivo evaluations. Int J Nanosci:1950036. https://doi.org/10.1142/S0219581X19500364.

35. Ferracini R, Martínez Herreros I, Russo A, Casalini T, Rossi F, Perale G (2018) Scaffolds as structural tools for bone-targeted drug delivery. Pharmaceutics. 10(3):1-26

36. Şenel S, Kremer MJ, Kaş S, Wertz PW, Hıncal AA, Squier CA (2000) Enhancing effect of chitosan on peptide drug delivery across buccal mucosa. Biomaterials. 21(20):2067-2071

37. Van der Lubben IM, Verhoef JC, Borchard G, Junginger HE (2001) Chitosan and its derivatives in mucosal drug and vaccine delivery. Eur J Pharm Sci 14(3):201-207

38. Haeri MR, White K, Qharebeglou M, Ansar MM (2015) Cholesterol suppresses antimicrobial effect of statins. Iran J Basic Med Sci 18(12):1253-1256

39. Masadeh M (2012) Antibacterial activity of statins: a comparative study of atorvastatin, simvastatin, and Rosuvastatin. Ann Clin Microbiol Antimicrob 4: 123-131

40. Mai-Prochnow A, Clauson M, Hong J, Murphy AB (2016) Gram positive and gram negative bacteria differ in their sensitivity to cold plasma. Sci Rep 6(1): 1-15

41. Ragab HS (2014) Synthesis and in vitro antibacterial properties of hydroxyapatite nanoparticles. J Pharm Biol Sci 9(1):77-85

42. Morsy MA, Abdel-Latif RG, Nair AB, Venugopala KN, Ahmed AF, Elsewedy HS (2019) Preparation and evaluation of atorvastatin-loaded nanoemulgel on wound-healing efficacy. Pharmaceutics. 11(11):1-11

43. Rosińczuk J, Taradaj J, Dymarek R, Sopel M (2016) Mechanoregulation of wound healing and skin homeostasis. Biomed Res Int:1-13

44. Garg VK, Paliwal SK (2011) Wound-healing activity of ethanolic and aqueous extracts of Ficusbenghalensis. J Adv Pharm Technol Res 2(2):110-114

45. Bhaskar A, Nithya V (2012) Evaluation of the wound-healing activity of Hibiscus rosasinensis L (Malvaceae) in Wistar albino rats. Indian J Pharm 44 694-698

46. Murthy S, Gautam MK, Goel S, Purohit V, Sharma H, Goel RK (2013) Evaluation of in vivo wound healing activity of bacopamonniera on different wound model in rats. Barschak AG, editor. Biomed Res Int:1-9

\section{Publisher's Note}

Springer Nature remains neutral with regard to jurisdictional claims in published maps and institutional affiliations.

\section{Submit your manuscript to a SpringerOpen ${ }^{\circ}$ journal and benefit from:}

- Convenient online submission

- Rigorous peer review

- Open access: articles freely available online

- High visibility within the field

- Retaining the copyright to your article

Submit your next manuscript at $\boldsymbol{\nabla}$ springeropen.com 